(VR / AR), 3D-друк, робототехніка, нанотехнології [1]. Такі тенденції вимагають, щоб майбутні медики та фармацевти починали опановувати сучасні комп'ютерні та інформаційні технології вже на перших курсах під час вивчення природничих дисциплін. Це сприятиме формуванню у студентів світогляду відповідно до сучасних реалій, де навчання, наука, медицина і комп'ютеризація є нерозривними складовими.

\title{
Література:
}

1. Соколенко Л. Ф., Линник С. О. Впровадження засобів цифрового управління в сфері охорони здоров'я. URL: http://www.dy.nayka.com.ua/ pdf/8_2020/55.pdf (дата звернення: 03.07.2021).

2. Струтинська О. В., Умрик М. А. Сучасні освітні тренди в умовах розвитку цифрового суспільства. URL: http://www.innovpedagogy.od.ua/ archives/2020/26/42.pdf (дата звернення: 02.07.2021).

DOI https://doi.org/10.30525/978-9934-26-114-5-41

\section{ЗДОБУТКИ В ЦАРИНІ МЕТОДИКИ НАВЧАННЯ ЛІТЕРАТУРИ В ПЕРІОД КІНЦЯ ХІХ - ПОЧАТКУ ХХ СТОЛІТТЯ}

\author{
Степаненко О. К. \\ кандидат філологічних наук, доцент, \\ докторант кафедри методики викладання світової літератури \\ Національний педагогічний університет імені М. П. Драгоманова \\ м. Київ, Украӥна
}

Методична теорія наших днів - це в першу чергу узагальнення досвіду викладання літератури в сучасній школі. Вона враховує i передовий досвід минулого, спирається на цінні напрацювання педагогів-словесників, враховує уроки та розвиває кращі традиції літературної освіти. Історія методичної думки на наших теренах нероздільно пов'язана із суспільним розвитком, становленням літератури, з іменами видатних діячів науки й культури, літераторів і педагогів, перших авторів наукових праць, навчальних посібників, статей 3 проблем теорії та історії словесності, з питань навчання та виховання.

В історії методики викладання літератури XIX століття яскраво виявилися три течії - логіко-стилістична, освітньо-виховна і етикоестетична, які розширювалися, поглиблювалися та інтегрували на наступних етапах розвитку науки і відіграли важливу роль 
у становленні сучасної теорії та технології вивчання літератури в середній школі.

Прихильники логіко-стилістичної течії на перший план ставили розвиток навичок мислення i мовлення учнів. Федір Буслаєв наголошував на потребі безпосереднього знайомства учнів з текстами художніх творів, але їх вивчення зводив до так званого філологічного аналізу [1, с. 215-328].

На наступному етапі розвитку методики навчання літератури, відомому як період ліберальних реформ (за Я. Ротковичем), урізноманітнювався процес вивчення літературного твору завдяки використанню нових організаційних форм (бесіда, літературна екскурсія тощо), але суттєво послабився історичний принцип вивчення мистецтва слова. Перевага надавалася іманентному читанню (позаісторичному, позасоціальному), що було природною реакцією на еклектичну методологію культурно-історичної школи [6, с. 10].

Представники освітньо-виховної течії у методиці літератури Василь Водовозов і Володимир Стоюнін наголошували на вихованні високих моральних якостей учнів засобами художнього слова; вони особливого значення надавали формуванню світогляду, громадянської та патріотичної позиції учнів, вихованню кращих моральних якостей засобами художнього твору через вплив на естетичні почуття. I здійснювати це радили через аналіз ідейного змісту на основі розгляду певних значимих компонентів твору [2; 7].

Наприкінці XIX - на початку XX століття відбувалося національнокультурне відродження українців, зокрема в гуманітарній сфері. Значний дидактичний потенціал мали твори українських письменників, написані на теми навчання й виховання молоді.

На цьому етапі особливо популярним став національний аспект. В українській літературознавчій та педагогічній думці це відбулося завдяки наполегливій праці Івана Франка. Учений i письменник намітив вузлові питання національного контексту вивчення художньої літератури в середній школі: рідна мова, національний характер, національний колорит, специфічна окраса мистецьких творінь, національний «дух». При розгляді художніх творів учений завжди відштовхувався від того, що національний зміст художньої творчості уяскравлюється характеристикою психологічних і культурних ознак народу, формулюючи тим самим доцільність взаємозв'язаного визначення зазначених аспектів у процесі аналізу творів мистецтва слова [8, с. 66]. При цьому вчений підкреслював, що національна специфіка літератури жодною мірою не суперечить принципам інтернаціоналізму $[9$, c. 505]. 
Представники етико-естетичної течії великого значення надавали емоціям та почуттям учнів, які виникають і розвиваються у процесі безпосереднього i яскравого переживання поетичних образів (за В. Голубковим) [3, с. 48]. На їхню думку, виникнувши 3 мови, мистецтво слова також характеризується зовнішньою словесно формою, внутрішньою формою (образністю) та змістом, або ідеєю. Ідея твору завжди суб'єктивна. Вона обумовлена аперцепцією, тобто тими асоціаціями письменника, які склалися на основі його попереднього досвіду, і читача, що сприймає твір.

Не менш значущим був внесок теорії О. Потебні та його послідовників у розробку поетапного вивчення художнього твору, теорії розвитку читацької, дослідницької та творчої діяльності. Сформульовані вченим теоретичні положення стали основою технологічного підходу до вивчення літературного твору.

Представник психологічної школи В. Данилов посилався на основи естетичної теорії та психологічний принцип О. Потебні, і доводив, що в основу методики навчання літератури має бути покладено думку про те, що заслуга митця не в тому мінімумі змісту, який передбачався у процесі творення, а в гнучкості образу, у силі внутрішньої форми пробуджувати найрізноманітніші змісти [4, с. 53]. Усі положення методики літератури, на глибоке переконання вченого, мають бути «узгоджені, наскільки це можливо, 3 даними психології» [4, с. 53], і мати своєю педагогічною метою розвиток розумової діяльності учнів, зокрема здібностей спостерігати явища, зіставляти їх, аналізувати й синтезувати факти і через ці процеси доходити висновків.

Подібні твердження переконують, що потреба грунтовної роботи над компонентами художнього твору для визначення художньої вартості загалом зумовлена розвитком суспільства, науки і культури II-ї половини XIX ст., а формування читацьких умінь та якостей, серед яких належне місце належить умінням характеризувати місце та роль образів-персонажів у загальній структурі художнього твору, вважалося способом підвищення якості вивчення словесності в школі.

Здобутки «харківської школи» О. Потебні стали знаковими для розвитку методики навчання літератури. У передмові до першого тому видання «Питання теорії і психології творчості» 1907 р. Б. Лезін заявляв, що непростимо далі дотримуватися схоластичних понять, які ще панують у методиці літератури і в середні школі, і закликав вивчати і використовувати творчу спадщину О. Потебні та О. Веселовського.

Науково обгрунтований психологізм до сприйняття творів мистецтва слова, як і потреба врахування соціального та історичного контексту, наприкінці XIX - початку XX століття не знайшли належної 
підтримки в науковому та вчительському середовищі. Зокрема Б. Ейхенбаум стверджував, що вони знецінюють вивчення самого тексту [5, с. 113].

Методичні пошуки кінця XIX - початку XX ст. були обумовлені боротьбою різних шкіл у літературознавстві, а також бурхливим розвитком експериментальної педагогіки та психології.

Отже, можна констатувати, що період становлення методики навчання літератури як галузі наукового знання визначався активним формуванням педагогічної теорії та розвитком шкільної практики вивчення літератури. Основні течії методики викладання літератури (логіко-стилістична, освітньо-виховна і етико-естетична), що сформувалися наприкінці XIX - початку XX ст. у працях відомих педагогів, знайшли певне продовження і поглиблення в науці, трансформувалися у два основні напрямки щодо розвитку літературної освіти в середній школі - «суспільний», який продовжував переважно традиції культурно-історичної школи, і «художній». Аналіз теоретичного i практичного доробку вчених і вчителів цього періоду переконує, що ці два напрямки тісно перепліталися у процесі розвитку, даючи поштовх до розвитку прогресивних методичних ідей.

\section{Література:}

1. Буслаев Ф. И. О преподавании отечественного языка. Москва: Либроком, 2010. С. 215-328.

2. Водовозов В. И. Избранные педагогические сочинения. Москва: Педагогика, 1986. С. 228.

3. Голубков В. В. Методика преподавания литературы. Москва: Учпедгиз, 1962. С. 48.

4. Данилов В. В. Литература как предмет преподавания. Москва: Тип. т-ва И. Д. Сытина, 1917. С. 53.

5. Ейхенбаум Б. М. О принципах изучения литературы в средней школе. Русская школа. 1915. № 12. С. 113.

6. Роткович Я. А. История преподавания литературы в советской школе. Учеб. пособие для студентов филол. специальностей пед. институтов, узд. 2-е, испр. и дополн. Москва: Просвещение, 1976. С. 10.

7. Стоюнин В. Я. О преподавании русской литературы. Избранные педагогические сочинения. Москва: Педагогика, 1991. С. 113.

8. Франко І. Я. Зібрання творів: У 50-ти т. Київ: Наук. Думка, 1955. T. XVII, C. 66.

9. Франко І. Я. Зібрання творів: У 50-ти т. К.: Наук. Думка, 1955. T. XVIII. C. 505. 